\title{
SPECIAL RECOGNITION The Indiana University School of Social Work: The First 100 Years!
}

\section{Rob Schneider}

On Oct. 24, 2011, the Indiana University School of Social Work formally celebrated its 100th anniversary at a dinner that drew nearly 400 people, including the President of Indiana University, Michael McRobbie, as well as state, city and civic leaders. President Barack Obama also sent a letter congratulating the School on its accomplishments.

The School's story starts with the opening of the Department of Social Service in Indianapolis in 1911. The opening of the Social Service Department makes the School of Social Work the oldest professional social work education program in the United States begun and continuously functioning as part of a university. The Social Service Department was part of the Department of Economics and Sociology in Bloomington, but it was housed with the School of Medicine in Indianapolis. The Department listed its objectives as: education, prevention and research.

Indiana University President William Bryan turned to Edna Henry, Ph.D., an Indiana University graduate, to lead the new Department. In a note to Henry, Dr. Bryan explained the University intended to establish a sub-Department of Sociology to study "charity problems in connection with the City Dispensary and later in connection with the City Hospital and also in order to render service to the deserving poor that come to the Medical School for assistance” (Bryan, letter to Edna Henry, June 3, 1911).

The new Department struck a bold note in its first annual report. "The Department must look through the individual patient to the society in which he lives and find there the causes which make individuals sick or which keep them so. Such work cannot be limited to the confines of one city. It must be state-wide. Indiana University can be satisfied with nothing less than better health, increased knowledge, and diminished poverty for the coming generations of all Indiana” (Indiana University, Social Service Department, 1913, p. 5).

"Much of the learning was experiential in nature. Students were assigned cases and learned by providing actual social services to people in need. The faculty of the new department developed a coherent curriculum and taught courses such as medical social work and social medicine. They also managed a laboratory for sociology students interested in social work. In addition, they administered hospital social services and supervised community volunteers who provided aid to patients and their families" (Busch et al., 2001, p. 85).

In 1918, Dr. Henry was elected the first president of the American Association of Hospital Social Workers. With America's entry into World War I, she was asked to work in the federal government's Surgeon General's Office to develop a program for social service in reconstruction hospitals to assist soldiers returning home from the war. In

Rob Schneider is Coordinator of External Relations for the Indiana University School of Social Work on the Indianapolis campus.

Copyright (C) 2011 Advances in Social Work Vol. 12 No. 2 (Fall 2011), iv-x 
September of 1920, illness forced Dr. Henry to submit her resignation. In April of 1921, Robert Neff, the registrar of the Indiana University School of Medicine and administrator of the Robert W. Long Hospital succeeded Henry as director.

The Department of Economics and Sociology of the College of Arts and Sciences assumed administrative control of the Social Service Program in 1921. The program took on a new name, the Indiana University Combined Course for the Training of Social Work. The program augmented students' liberal arts studies with professional social work training and service experience. Under this arrangement, students could complete the social work training program and earn a baccalaureate degree. Neff served as director for three years, then left to become administrator of the new James Whitcomb Riley Hospital, which opened in October of 1924, as well as administrator for the Robert W. Long Hospital.

Professor Ulysses Grant Weatherly stepped in to serve as director of the program in addition to teaching courses in Indianapolis and Bloomington, according to announcements for the 1926-27 school year (Rogers, 1983, p. 33). To comply with the educational standards of the American Association of Training Schools, the Indiana University Training Course required undergraduate coursework in sociology, economics and psychology. Students were expected to complete foundation studies followed by one of five specializations: medical social work, family social work, child welfare, visiting teaching, and public social work. Students also completed field practicum experiences in agencies that supported one or more of these specializations.

In the early 1930s, the Combined Training Course for Social Work was reorganized as a two-year graduate program in Indianapolis as part of an effort to promote social work as a profession. The program provided coursework for three specializations, including social casework, public welfare administration, and social statistics. Students completed a research thesis and oral examination in addition to classroom and field practicum experiences.

In 1935 the Combined Training Course became a division within the Department of Sociology. The program shifted its curriculum to enable graduates to work at newly created public welfare agencies created to address problems brought on by the Great Depression. For the period from 1937 to 1942 the Training Course provided professional education for social work to those men and women who chose social service as their careers. It offered a two-year graduate program of professional courses, field work, and research leading to the Master of Arts degree in Social Service. Its work was fully accredited by the American Association of Schools of Social Work. "Strong programs in family welfare, child welfare, public welfare, and treatment of delinquents have been maintained and further developed” (Evans, 1943, p. 2). This 1937-42 report further points out that special attention was given to the professional education needs of untrained and partly trained workers employed in social agencies throughout the state.

World War II drastically affected the social service program. In the program's report for 1942-44, Louis Evans, who was in charge of the Training Program, wrote they had to make several "drastic adaptations to the war situation. A marked decline in enrollment occurred in the face of an increased demand for qualified social workers in Indiana and 
throughout the country” (Evans, 1944, p. 1). The program adopted an accelerated yearround war schedule that shortened the time for completion of the standard four semester program from 21 to 16 months

In 1944, the Board of Trustees established the Division of Social Work as a unit within the College of Arts and Sciences, separate from the Department of Sociology. Physically, the Division remained in Indianapolis and provided professional education leading to the degree of Master of Arts in Social Service and continued to collaborate with the College in offering an undergraduate major in Social Service on the Bloomington campus (Busch et al., 2001, p. 87)

In November of 1944, Dr. Grace Browning, a nationally regarded social work educator from the University of Chicago School of Social Service Administration, was named director of the Division of Social Work. The Division opened in the fall of 1945 with six full-time faculty members. In its report for 1945-46, the division reported having 39 full-time and 50 part-time students for the 1945-46 year.

Indiana University's Labor Studies program, which would become part of the School of Social Work in 2007, got its start in 1946 at the direction of Indiana University President Herman B Wells. Under his administration, the University assumed the responsibility and commitment to provide workers and unions the education they would need to contribute to a modern, efficient economy.

Dr. Browning was the first American social worker to be chosen for an assignment on the Technical Assistance Program of the United Nations as a consultant to the Italian Schools of Social Work in 1951. However, on the day she was to leave for Italy, Browning died in Robert W. Long Hospital following a short illness. She was 46.

The University selected Mary Hammond Houk, who had joined the Division in 1945 as the director of field work, to lead the Division. A native of Missouri, Houk received her BA degree from the University of Missouri in 1922 and a Master's degree from the University of Chicago's School of Social Service Administration in 1939. "Primarily because of Houk's success in enhancing the program's reputation, the Board of Trustees upgraded the status of the Division in 1966 by creating the Graduate School of Social Service. Director Houk was appointed Dean of the School and students earned the Master of Social Work degree” (Busch et al., 2001, p. 88).

"Professor Walter Johnson became Acting Dean of the School during the interim period following Houk's retirement. During his short tenure, Johnson was able to obtain a commitment from university officials to move the School from its long-time location at 122 E. Michigan Street, to a building to be built on the new campus of Indiana University in Indianapolis” (Busch et al., 2001, p. 88).

Dr. Richard G. Lawrence, who was a faculty member and associate dean of the George Warren Brown School of Social Work at Washington University in St. Louis, was named dean in 1967. In its 1967-68 annual report, the School of Social Services reported having 135 full and part-time students and a full-time faculty of 19 professors as well as 7 lecturers, of which 6 were part-time. During Dr. Lawrence's tenure as dean, the MSW curriculum was reorganized. "As partners in a national curriculum project, the 
School attempted to cross-integrate its course-work content by organizing plenary sessions and discussion groups instead of traditional classes. By 1969-70 block field placements were introduced for the first time and a community organization concentration complemented those in social casework and social group work" (Busch et al., 2001, p. 88).

The School moved from its offices in downtown Indianapolis into Cavanaugh Hall on the IUPUI campus in 1971. The following year the School proposed new curricular designs for the new Bachelor of Social Work and Associate of Science in Human Services programs. Dr. Cyrus Behroozi was appointed coordinator for Undergraduate Development. In 1973 the proposal was accepted by the Indiana Commission on Higher Education and the same year the Graduate School of Social Work was renamed the Indiana University School of Social Service. The BSW program graduated its first class in 1975. "The School's new BSW curriculum was designed to prepare students for beginning professional social work practice with a focus on the problem-solving process. Over several years this curriculum was implemented on the Indianapolis, Richmond and Bloomington campuses, replacing the undergraduate social service program that had been offered for so many decades in cooperation with the College of Arts and Sciences in Bloomington" (Busch et al., 2001, p. 89). The BSW program was accredited by the Council on Social Work Education in 1975 and has been accredited ever since.

In 1976-1977, the Associate degree was started at Indiana University East under the leadership of Professor Valerie Chang. Between 1980 and 1994, the School offered the first three years of the baccalaureate program on the Indiana University East campus, with students transferring to Indianapolis for the fourth year. In 1994, the Council on Social Work Education approved the fourth year of the program on the IU East campus.

Dr. Leonard Schneiderman was named dean of the school in 1977 and Dr. Cyrus Behroozi was appointed the first Associate Dean of the School. That same year, the School's name was changed to the Indiana University School of Social Work and it offered the Associate of Science in Human Services, the BSW and MSW degrees.

The origins of doctoral education at Indiana University date back to Dean Lawrence, but the development of such a program took on an added urgency under Dr. Schneiderman who made it one of the School's top priorities. Dr. Schneiderman was convinced that the realization of the School's aspirations for national prominence would inevitably require the development of a research infrastructure that could lead to the creation of new knowledge. A faculty planning group was formed in 1979 and set about preparing a formal proposal to be submitted to the Indiana Commission on Higher Education. The committee opted for the DSW degree because of the lack of PhD's on the school's faculty.

The Commission tabled the DSW proposal in 1980 pending a report on the progress of the expansion of the MSW program to three additional Indiana University Campuses and the University of Southern Indiana. One year later, the Commission voted seven to six against approval, citing the failure on the part of the School to mount programs on any of the regional campuses. The School had requested \$1.6 million to implement the 
approved MSW programs, but in the absence of any additional funding to support the expansion, it created the option of a Weekend Work Study program at the graduate level.

In 1981, the School moved from Cavanaugh Hall to the fourth floor of the new Education-Social Work Building. A year later, Dean Schneiderman resigned his position as dean. Dr. Beulah Compton served for a year as Acting Dean and was then followed by Dr. Powers, who served two years as Acting Dean. Dr. Sheldon Siegel was appointed dean of the school in 1984. Dr. Siegel previously had been Director of the University of Cincinnati School of Social Work for six years and before that an Associate Professor at The University of Michigan School of Social Work.

Dr. Siegel continued the School's efforts to increase the diversity of both its faculty and student body. Dr. Schneiderman was responsible for developing the School's affiliation with the Council on International Programs (CIP), an international initiative that was instrumental in bringing hundreds of human service professionals from more than 80 countries around the world to the IUPUI campus. The international and interdisciplinary initiative was sustained by Dr. Siegel under the leadership of Professor David Metzger. To enhance statewide access to graduate social work education, the School initiated a part-time weekend Work Study program on the Indianapolis Campus.

In the late 1980s, Dr. Siegel reconvened a group of faculty to consider the feasibility of submitting a new proposal for a doctoral degree program. In the years that intervened since the submission of the original proposal, the makeup of the faculty had changed dramatically, both in terms of its academic credentials and racial diversity and the School applied for a $\mathrm{PhD}$ program in 1991. The School's proposal for a $\mathrm{PhD}$ program was approved by the Commission on Higher Education. The first cohort of $\mathrm{PhD}$ students began coursework in 1994.

In 1994, Dr. Roberta Greene became the School's fifth dean. Dr. Greene built upon her predecessors' efforts to develop a variety of community-based field units headed by teacher/practitioners. Dr. Greene also secured major funding that dramatically enhanced the computer and technological resources of the School and contributed to a growing interest and capacity for research and scholarly writing among social work faculty and students.

Dr. Michael Patchner became the sixth dean of the School in 2000. The son of an Appalachian coal-miner, he served as the Associate Dean and Professor at the University of Pittsburgh School of Social Work for eight years before coming to Indiana University. Previously, he served as Dean and Professor of the West Virginia School of Social Work. In the School's December 2000 newsletter, Dean Patchner outlined his goals for the School. Among his top priorities were research and scholarship. "As we need to produce new knowledge to inform practice and the social work profession, I desire for the school to be recognized, both nationally and within Indiana, for having a reputation for quality and service, and I look for the School to be well-connected to state government and social service organizations throughout the state" (Patchner, 2000). The school's new journal, Advances in Social Work, started in 2000 to provide an additional outlet for the dissemination of social work scholarship and to bring additional recognition to the School. 
In 2004, the School celebrated another milestone with the graduation of the first class of BSW students on the Bloomington campus. Previously, students on the Bloomington campus needed to transfer to the Indianapolis campus to complete their senior year in the BSW program.

State leaders turned to the School in 2004 to provide leadership for the Indiana Commission on Abused and Neglected Children and Their Families. Dean Patchner served as chair of the Commission, whose recommendations formed the basis for changes the state made to better protect children in Indiana.

During the 2005-06 academic year, the school marked a milestone as its enrollment topped 1,000 students on all of its campuses for the first time. One of the factors contributing to the School's growth was the addition of the MSW program at Indiana University-Purdue University, Fort Wayne.

The School assumed administrative duties for Indiana University Labor Studies Program in 2007. Labor Studies courses are offered on all of Indiana University's campuses, and the program offers degrees ranging from an Associate of Science to a Bachelor of Science in Labor Studies. Dr. Irene Queiro-Tajalli, the Executive Director of Undergraduate Education, took on the role of Interim Executive Director of the Labor Studies Program as well.

After Gov. Mitch Daniels was elected governor and created the Department of Child Services, the School enhanced its partnership with the agency to better train employees of the agency as well as students who wanted to become case managers with DCS. The School initiated a program where employees in public child welfare were able to earn their MSW degrees.

The addition of the Labor Studies program and the growth of the Child Welfare training program were among the reasons the school saw the number of its faculty jump from about 25 faculty members in 1998 to about 70 in 2011. The School's growing and enhanced programs were reflected in national rankings - for 2008 the U.S. News and World Report ranked the School's MSW Program 26th out of more than 200 programs.

After extensive discussions, the School began a new initiative in 2009 that linked the Social Work program to its earliest days of medical-related social work. With philanthropic support from Jason Baker, a punter with the Carolina Panthers, the School of Social Work collaborated with Riley Children's Hospital to establish an academic certificate program focused on training individuals to specialize in a career that provides support to children with special health needs and their families.

The State of Indiana again turned to the School of Social Work in 2010 asking for its help to resolve the growing problem of children living in poverty. Dean Patchner was asked to serve as chair of the Commission on Childhood Poverty in Indiana. The Commission is charged with recommending how the state can reduce childhood poverty by 50 percent by 2020 . 
The School and its faculty have expanded their focus to include a global perspective. It has developed partnerships that with universities in Kenya, China and Croatia that resulted in special opportunities for students and faculty members alike.

While online courses have been part of the BSW program since 2001, the School moved to increase its online distance education efforts at the MSW level. The School is planning an online Master of Social Work program, MSW Direct, to serve students who cannot come to our campus.

The size and scope of the School of Social Work has changed drastically since Edna Henry sat in her director's chair determined to see the new Social Service Department succeed. One aspect though remains very much the same 100 years later. The same passion that Dr. Henry and those that followed her brought to bear on their work is still very much in evidence today as we celebrate a century of giving hope and changing lives.

\section{References}

Busch, M., Powers, G. T., Metzger, D., Behroozi, C. S., Siegel, S., \& Cournoyer, B. R. (2001). Indiana University School of Social Work: 90 years of professional education. Advances in Social Work, 2, 83-100.

Evans, L. (1943). Report of the Training Course for Social Work 1937-42, Indianapolis: Indiana University.

Evans, L. (1944). Report of the Training Course for Social Work September 1, 1942August 31, 1944, Indianapolis: Indiana University.

Indiana University, Social Service Department. (1913). Report of the Social Service Department 1911-12 and 1912-1913. Bloomington, IN: Author.

Patchner, M. (2000, December). “Dean’s Message,” Network, p.1.

Rogers, H. C. (1983). Seventy years of social work education at Indiana University. Indianapolis: Indiana University.

\section{Author note:}

Address correspondence to: Rob Schneider, Indiana University School of Social Work, 902 West New York Street, Indianapolis, IN 46202. Email: robschn@iupui.edu 